\title{
胆管ドレナージカテーテルに対する胆管の組織反応に関する研究
}

\author{
名古屋大学医学部第 1 外科
}

岡本 勝司 長谷川 洋 二村 雄次

\section{A STUDY ON TISSUE REACTION OF THE BILE DUCT TO THE BIRIARY DRAINAGE CATHETER}

\section{Katsushi OKAMOTO, Hiroshi HASEGAWA and Yuji NIMURA}

The First Department of Surgery, Nagoya University School of Medicine

\begin{abstract}
胆管ドレナージカテーテルの材質による胆管の組織反応の差を知る目的で, 家鬼を用いてカテーテ ルによる胆道内瘦化モデルを作成し, シリコン, 塩化ビニール, ポリウレタン製のカテーテルに対す る組織反応を検討したところ, 塩化ビニール留置群に扔いて粘膜剝脱, 炎症性細胞浸潤, 結合織増生 などの炎症反応が高度であった。また臨床例において塩化ビニール製カテーテルによる胆管粘膜の変 化を経皮経肝胆道鏡により観察したところ, ビラン, 肉芽組織形成が観察され，これらの所見は病理 組織学的には，粘膜の剝脱と，これに続くフィブリンの析出，肉芽形成によるものと判明した。
\end{abstract}

索引用語：胆管ドレナージカテーテル，胆管の組織反応，経皮経肝胆道鏡，胆管の肉芽組織

\section{I. 緒 言}

近年，胆道疾患に対する診断および治療を目的とし て胆管や胆囊内にドレナージカテーテルを留置する機 会が増加する傾向にある。以前より経皮経肝胆管ドレ ナージ (percutaneous transhepatic cholangial drainage : PTCD) ${ }^{1}$ 施行例ではカテーテルの留置されてい る胆管の壁肥厚や胆管壁外にまで及ぶ線維化がみられ たり, 経皮経肝胆道内視鏡 (percutaneous transhepatic cholangioscopy: PTCS $)^{2) \sim 5)}$ 施行時にはカテー テルの刺激による粘膜の変化が認められることが経験 されている6)。このように胆管内に異物であるカテー テルを留置しておくことにより, 胆管粘膜や胆管壁に さまざまな組織反応が惹起されることが知られている が788), カテーテルに対する胆管の組織反応を観察した 研究は少ない。

\section{II. 目 的}

本研究では胆管ドレナージカテーテルに対する胆管 の組織反応とカテーテルの材質による反応の差異を知 る目的で, 家鬼を用いて, カテーテルによる胆道内瘦 化モデルを作成し， 3 種類の材質による組織反応の差

$<1989$ 年 4 月 12 日受理 $>$ 別刷請求先：岡本 勝司 T466 名古屋市昭和区鶴舞町65 名古屋大学医学部 第 1 外科
異を経時的に観察した。さらに臨床例において PTCS 施行時にみられるカテーテルの刺激による胆管粘膜の 变化について検討を加えた。

\section{III. 材料および方法}

\section{1. 動物実験}

1）実験動物㧍よび材料

体重2 3kg の白色家鬼 66 羽を雌雄の別なく用い, オ リエンタル社製家鬼用飼料扣よび水道水を任意に摄取 させた。

被験材料として, 以下の 3 種類のカテーテルを用い た.

a）シリコン樹脂（富士システムズ社）

b) 軟質ポリ塩化ビニール樹脂（住友ベークライト 社)

c）エーテル系ポリウレタン樹脂(クリニカルサプラ イ社)

上記の材質はいずれも医療用グレードのものを使用 し, サイズは外径 $1.0 \mathrm{~mm}$, 内径 $0.5 \mathrm{~mm}$, 長さ $2.0 \mathrm{~mm}$ に 調製し実験に使用した。

2）実験方法

Pentobarbiturate sodium $30 \sim 50 \mathrm{mg} / \mathrm{kg}$ 静注によ り麻酔を施行. 右季肋下切開により開腹し総胆管の十 二指腸壁内流入部より $5 \mathrm{~mm}$ 肝側で総胆管切開を加党 
図 1 実験モデル

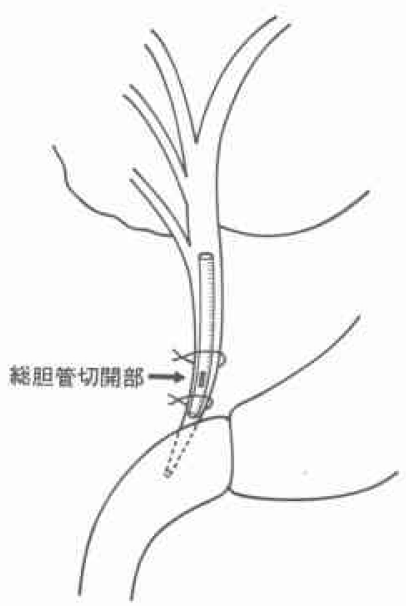

表 1 総胆管径の变化

\begin{tabular}{|c|c|c|c|c|c|}
\hline & 3 日 & 10 & $2 \mathbf{x}$ & 3) & $4 \pi$ \\
\hline$S$ 群 & $\begin{array}{c}7.3 \pm 1.1 \\
(k=3)\end{array}$ & $\begin{array}{c}7.0 \pm 1.3 \\
(n=3)\end{array}$ & $\begin{array}{c}5.8 \pm 1.2 \\
(n=4)\end{array}$ & $\begin{array}{c}6.6 \pm 2.1 \\
(n=5)\end{array}$ & $\begin{array}{c}8.0 \pm 2.4 \\
(n=5)\end{array}$ \\
\hline U 辟 & $\begin{array}{c}6.0 \pm 2.0 \\
(a=3)\end{array}$ & $\begin{array}{c}8.0 \pm 0.6 \\
(n=3)\end{array}$ & $\begin{array}{c}8.6 \pm 1.1 \\
(1=3)\end{array}$ & $\begin{array}{c}10.3 \pm 1.8 \\
(n=3)\end{array}$ & $\begin{array}{c}9.6 \pm 2.1 \\
(n=5)\end{array}$ \\
\hline$V$ 群 & $\underset{(n=3)}{7.0 \pm 0.6}$ & $\begin{array}{c}8.3 \pm 1.2 \\
(x=3)\end{array}$ & $\begin{array}{c}8.2 \pm 1.4 \\
(n=5)\end{array}$ & $\begin{array}{c}9.0 \pm 1.3 \\
(a=3)\end{array}$ & $\begin{array}{c}8.8 \pm 2.6 \\
(n=5)\end{array}$ \\
\hline
\end{tabular}

前述のカテーテルを胆管内に挿入した。切開部の上下 を6-0 Prolene 糸により結禁してカテーテルを固定 し，胆道内瘻化モデルを作製した（図 1).カカテーテル 留置後, 3 日, 1 週, 2 週, 3 週, 4 週目から最長 8 力月目に犠牲解剖し, 胆管を摘出し, 同時に下大静脈 から採血した。摘出標本は肉眼的観察, 計測执よび写 真撮影を行った後, ただちに $10 \%$ \%ルマリン液に浸漬 し固定した、実験群はシリコーン製カテーテル留置群 (以下 S 群), ポリウレタン製カテーテル留置群 (U 群), 塩化ビニール製カテーテル留置群 (V群)の3群 にわけ, 手術後 3 日から 4 週目までは各群 3 羽から 6 羽を作製した(表 1)。この他に長期観察例として，8 力月 ( $\mathrm{V}$ 群), 4 力月 ( $\mathrm{S}$ 群), 3 力月 ( $\mathrm{U}$ 群), 2 力月 （V群）観察例を各 1 羽ずつ作製した。

\section{3) 観察事項}

a）胆管の肉眼的形態, b) 胆管外径の測定, c）血液 生化学的検查, d) 病理組織学的検索

摘出標本はカテーテルの固定に使用した糸（切開部 より肝側の糸) $10 \mathrm{~mm}$ 肝側で胆管の長軸に直角方向
の切片を作製し，パラフィン包埋後，薄切して， Hematoxylin-Eosin 染色 (H-E 染色), Azan-Mallory 染色 (A-M 染色), Elastica-van Gienson 染色 (E-V 染 色）を行って光学顕微鏡下に観察した。

2. 臨床例における経皮経肝胆道鏡による胆管粘膜 の観察

1) 対象と方法

対象は1977年 4 月から1984年12月まで当科で PTCSを施行した211例で，対象疾患の5ち悪性疾患 㯜癌 40 例, 胆管癌 30 例, 胆震癌 24 例, 乳頭部癌 9 例, 肝癌 12 例, 胃癌 8 例の123例で, 良性疾患は肝内結石症 33例，総胆管結石症37例，良性胆管狭窄12例，慢性膵 炎 4 例，先天性胆管抎張症 4 例の88例である。

方法はすでに報告されているように, PTCSカテー テル（住友ベークライト社，塩化ビニール製）により PTCD 瘦孔を潮次抾張し, 瘦孔から胆道鏡を胆管内人 挿入し観察を行らものである2) 6).

使用した内視鏡は主としてオリンパス社製胆道鏡 CHF type 4B を用い, 症例によっては同社製 CHF B3 R および PTCS Model VI（試作モデル）を使用した。

カテーテルの刺激による変化と考えられる胆管粘膜 病変を胆道鏡下に観察し, 写真撮影を施行し, 適宜, 直視下生検を行った。また, PTCSカテーテル内から 採取された肉芽組織の病理学的検査も行った。病理組 織学的検索は H-E 染色を行い, 光学顕微鏡下に铙察し た。

\section{IV. 結 果}

\section{1. 動物実験}

1) 胆管の肉眼的形態

カテーテルの留置により総胆管は全例, 円筒状に拡 張した、腹腔内の癒着は軽度であったが，総胆管切開 部の後面に外側右葉（ヒトの右葉後区域に相当）が癒 着しているものが多かった。胆管の拡張形態, 癒着の 程度については各群間に一定の傾向はみられなかっ た。

2）総胆管径の変化

正常例の総胆管径は1.8土0.4mm であったが，実験 群に打いてはカテーテル留置後 3 日目からすでに7 $\mathrm{mm}$ 前後に抁張し, 以後はほとんど拡張せず, 最終的 に8 10mm 程度の拡張を示すものが多かった。総胆管 の拡張の程度は各群間に差はみられなかった（表 1 ）。

3）血液生化学的検查

gulutamic oxaloacetic transaminase (GOT), gulutamic pyruvic transaminase (GPT), alkaline 
表 2 ALPの変化 (Mean士S.E.)

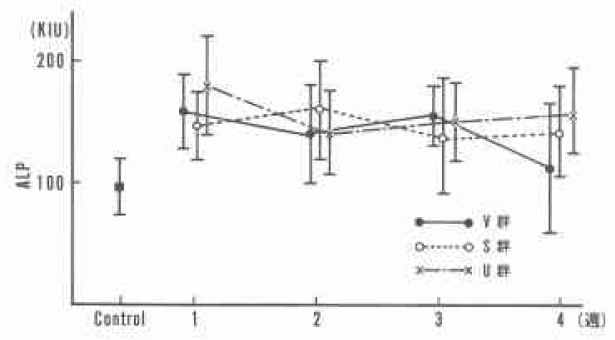

図 2 正常家鬼総胆管 $($ H.E. $\times 40)$

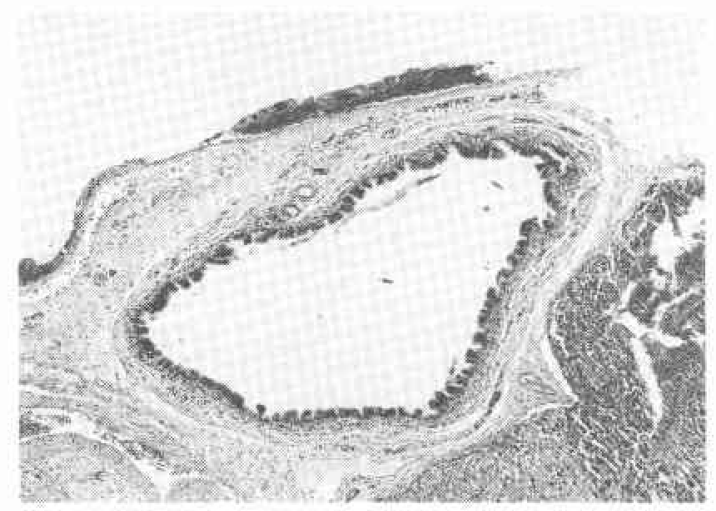

phosphatase (ALP), 総ビリルビンともに術後, 軽度 の上昇がみられ, 血液生化学検査上も胆汁うっ滞を示 唆する所見を呈していたが各群間に差はみられなかっ た（表 2).

4) 病理組織学的所見

a) 正常家鬼総胆管の組織学的所見

正常家鬼の総胆管組織は, 胆道癌取扱い規約 ${ }^{9} に よ$ るヒトの総胆管の組織構造分類に準じて分類すること ができる、寸なわち内層より粘膜上皮層 $(\mathrm{m})$, 線維矨 層 (fm), 外膜 (af) の 3 層に分類でき, 粘膜上皮は単 層円柱上皮からなり, 線維筋層は薄く, 結合組織が主 体で弾力線維が存在し, 胆管腺が存在している、線維 層の外僋は薄い粗性結合組織からなる外膜に包まれて いる(図 2,3 )。

b) カテーテル留置後の総胆管組織の変化

カテーテル留置後の胆管の病理組織学的変化を各層 別に観察すると, 粘膜上皮は術後 3 日から 1 週目には 各群とも剥脱しているものが多く，この時期には手術 操作の影響や胆管拡張の影響があるものと考兄られ た. 2 週目以後は V 群のみが粘膜の豩脱が著明で, $\mathrm{S}$ 群，U群に揖いては軽度であった。炎症反応が注ぼ安
図 3 正常家鬼総胆管 (H.E. $\times 100)$. 粘膜上皮層 $(\mathrm{m})$, 線維層（f）扣よび外膜（a）からなり壁は薄い。

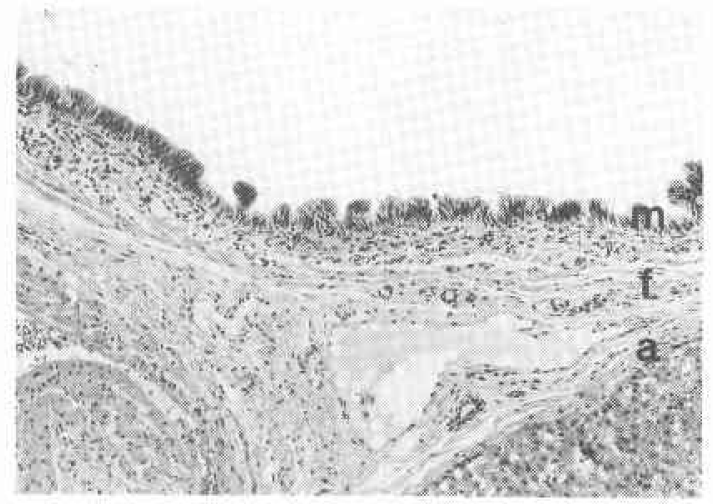

図 4 シリコーンカテーテル留置群（S 群）４週（H. E. $\times 100)$ ．粘膜上皮は保たれ，炎症性細胞浸潤は見 られず, 線維化も軽度である。

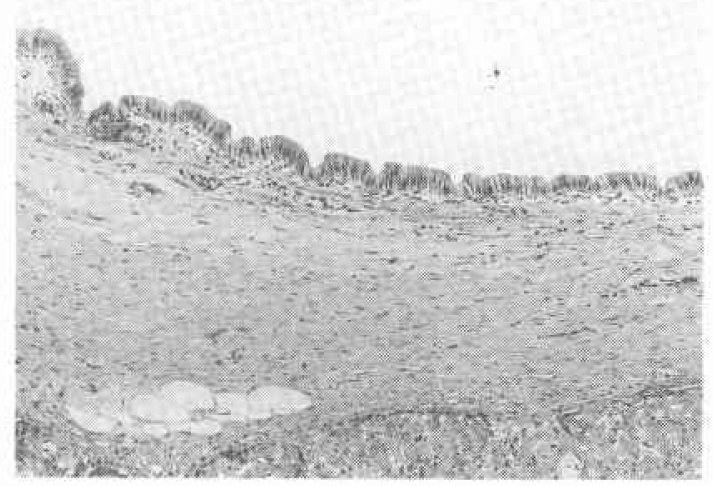

定すると考えられる 4 週目の粘膜の変化では, $V$ 群 5 羽のらち 2 羽に残存した粘膜の多尿性増殖像がみられ たが，S 群，U群においてはこのような所見はみられな かった (図 4〜 7).

線維筋層に拀いては著しい変化がみられ，その主な 所見は胆管腺増殖, 炎症性細胞漫潤, 毛細血管新生, 線維芽細胞の出現, 結合織増生, 線維化などである. 胆管腺は各群とも術後 1 週目から増殖する傾向がみ られ，2週から 3 週目には各群ともに増生する傾向が 著しいが，群による一定の傾向はみられなかった，胆 管壁の線維化が強くなると胆管腺は結合織に被包され 萎縮する傾向にあった。

炎症性細胞浸潤はリンパ球，組織球などが主体で， 1 週から 2 週目に多くみられ，特に胆管腺の周辺に細 
図 5 ポリウレタンカテーテル留置群(U 群) 4 週 ( H.

E. $\times 100)$ ，粘膜上皮は S 群とはぼ同様の所見を示

し, 線維化も強くない.

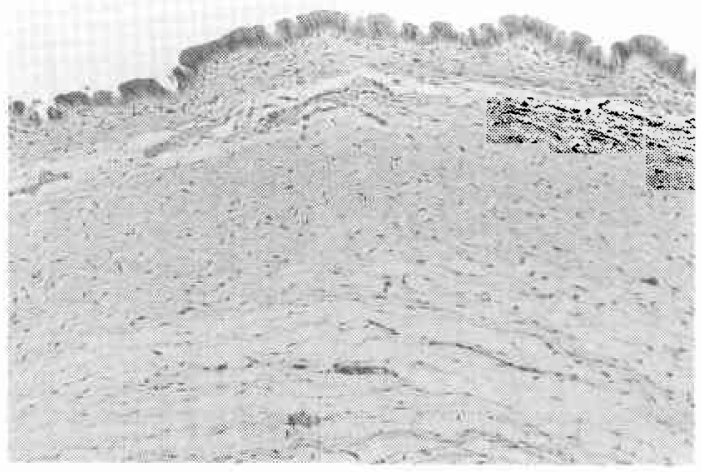

図 6 塩化ビニールカテーテル留置群 ( V 群) 4 週 ( $\mathrm{H}$. E. $\times 100)$, 粘膜上皮は永脱し, 結合織増生によって 被包され萎縮した胆管腺の周辺に炎症性細胞浸潤が みられる。

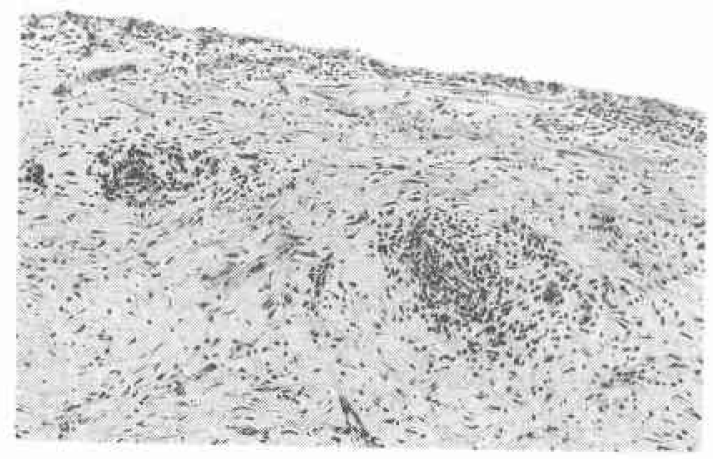

胞浸潤が著しかった、V 群においては他群に比し炎症 性細胞浸潤の所見が長期にわたり継続していた（図 6 ).

線維芽細胞は 1 週目から出現しはじめ, 2 週から 3 週目に増殖が著明である. 4 週目になると線維芽細胞 は次第に減少し線維化が完成する傾向にあったが，炎 症反応の持続している例では 4 週目でも線維芽細胞が 残存していた。

毛細血管の新生も線維芽細胞の出現と同様に一連の 炎症反応の過程で生じて来るものであり，線維芽細胞 の動向とほぼ同様の傾向を示していた。

胆管壁にみられる最も大きな変化は結合織の増生で あった。術後 1 週目からすでに結合織の増生が始まり,
困 7 塩化ビニール留置群 (4 週) (H.E. $\times 100)$ ，胆 管腺の增生が著明で, 粘膜上皮は一部で多層性に なっている。

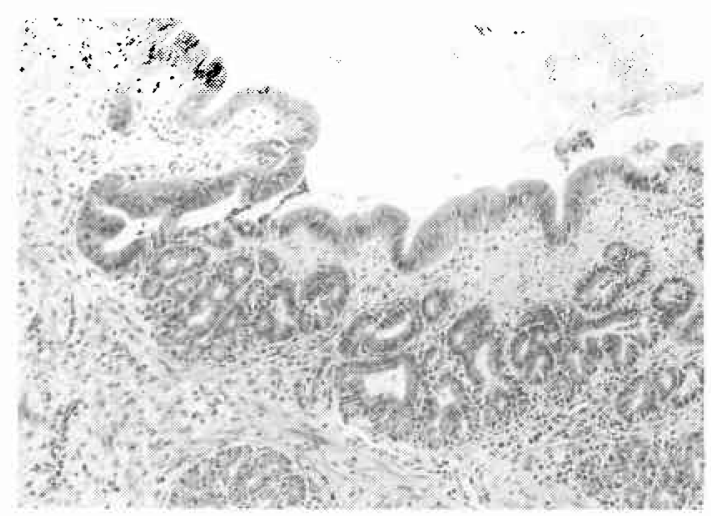

図 8 塩化ビニール留置群 ( 2 週) (H.E. $\times 10)$, 胆管 壁の肥厚が著しく，粘膜上皮は剥脱している.

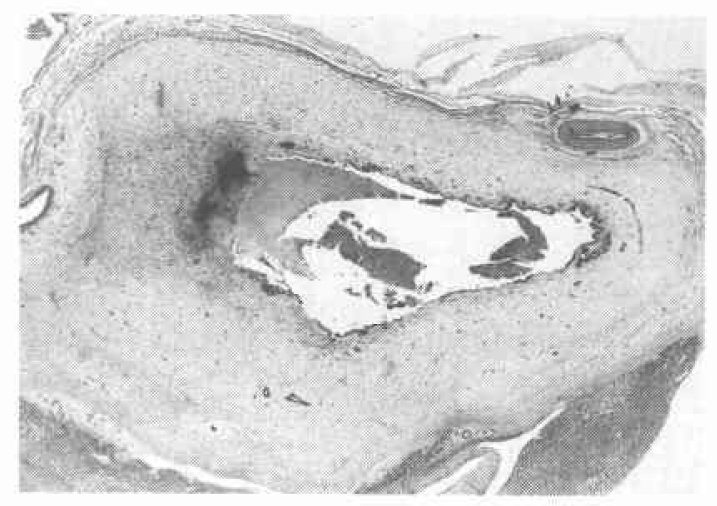

表 3 病理組織学的所見

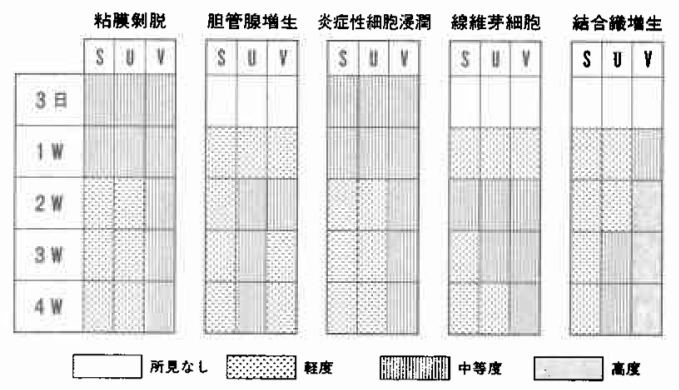

2 週， 3 週目と増生が進行し，4週目になると線維化 が始まっていた。結合織増生は S 群が最も軽度で, 次 いでU 群, $\mathrm{V}$ 群の順であったが, $\mathrm{S}$ 群とU 群の差はわ ずかであった（図 4 〜 ). 
図 9 ビランの内視鏡像。退色した凹凸不整の粘膜面 に出血を伴らビランを認める。

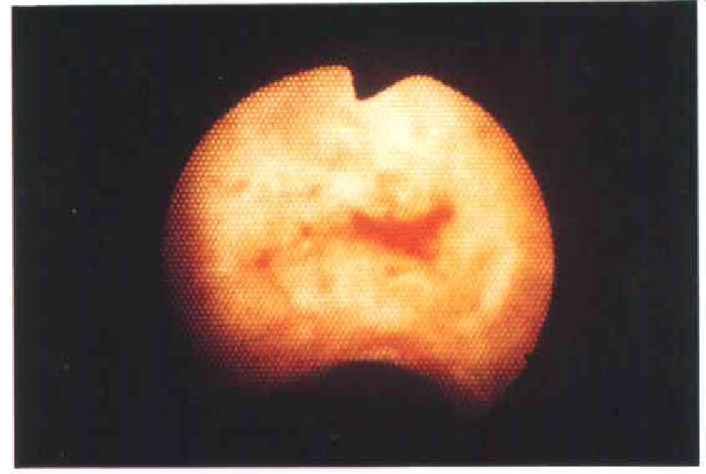

図10 肉芽組織の内視鏡像。黄色調で一部発赤した半 球状隆起

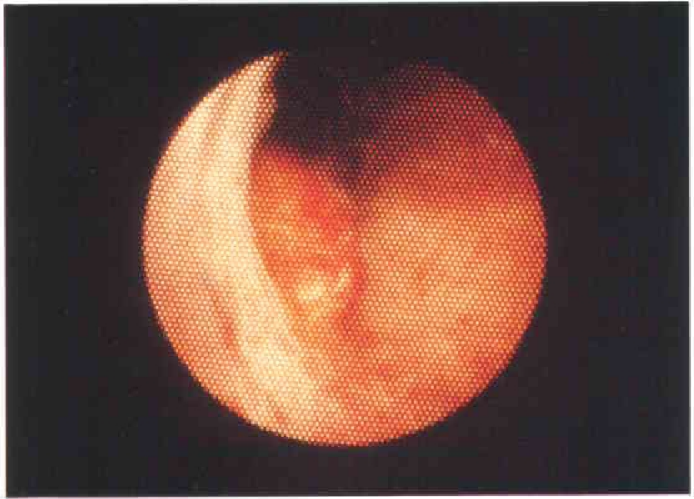

図11 肉芽組織の内視鏡像. 胆管壁からロウソク状に そり立った黄色で一部発赤を伴ら円柱状の肉芽組織

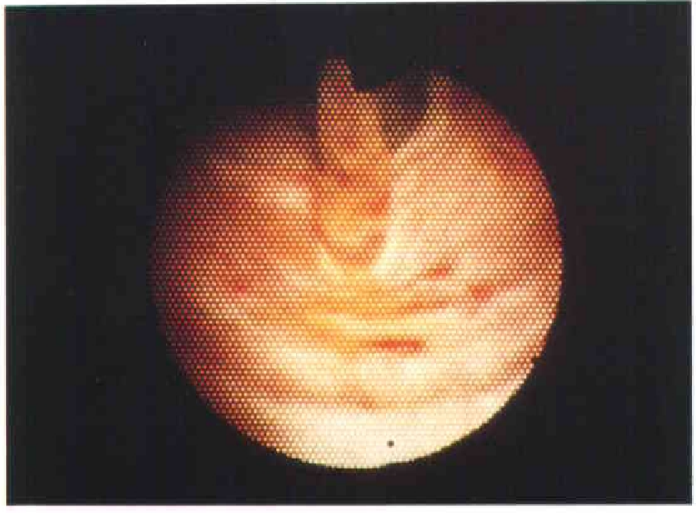

以上の傾向ををとめると, $\mathrm{S}$ 群と $\mathrm{U}$ 群では主に 3 週 目までに炎症性細胞浸潤ならびに胆管腺や結合織の増
図12 肉芽組織の X 線像 (PTCD 造影, Confluence stone 症例). カテーテルの先端の内腔に透亮像が認 められる。

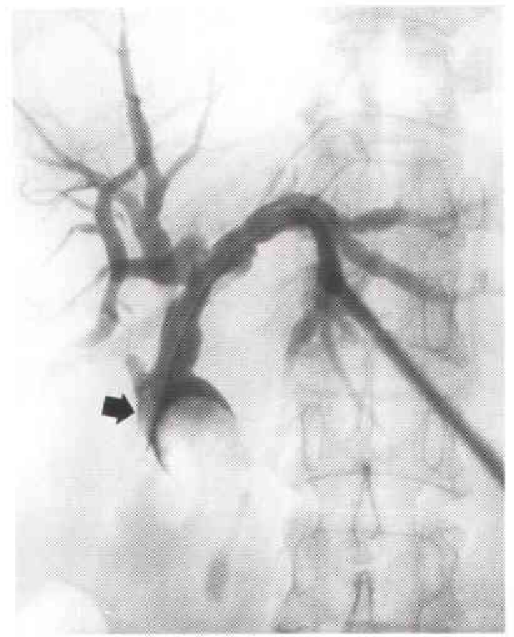

図13図12 同一症例の内視鏡像。黄色の結石の手前 に円柱状の肉芽組織が形成されている。

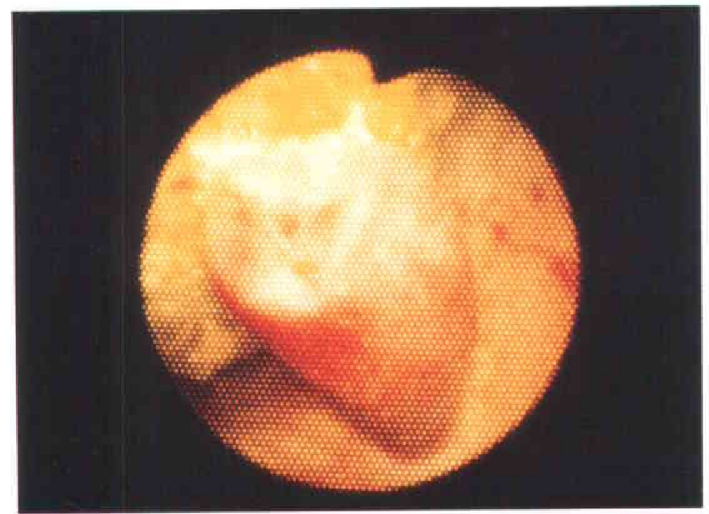

生などの炎症反応がみられ，4週目になると炎症反応 は消退し，線維化してくるのに対し，V 群では 4 週目 に损いても炎症反応が持続し，結合織の増生も高度で あることが明らかとなった（表 3 ）。

2 力月以上の長期観察例に拈いてはV 群で炎症 反応は消失しており，胆管壁の線維化が主な所見と なっていた。長期観察例の粘膜上皮は軽度の萎縮を示 し，増殖性変化を示したものはみられなかった。

2、臨床例に和忷る経皮経肝胆道鏡による胆管粘膜 の観察

詳細に観察すればカテーテルの影響による胆管粘膜 の変化は全例に認められるが，その所見を本来の胆道 
図14肉芽の組織像 $($ H.E. $\times 100)$ 。炎症性細胞浸潤, 線維芽細胞，毛細血管の増生がみられ，肉芽組織の 像を示している。

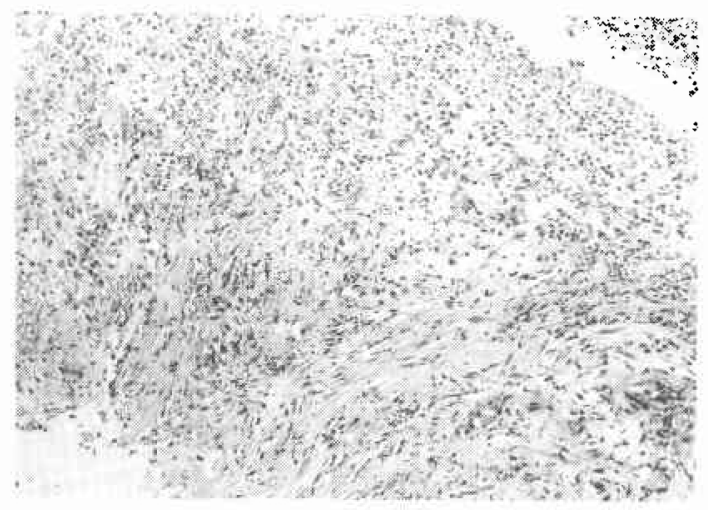

病変,すなわち胆管炎, 胆石の影響による変化などと 峳密に区別することは不可能であったＰTCS施行時 には程度の差はあるものの, 全例に胆管粘膜の発赤, 出血, ビラン, 浮腫などの変化が認められ, どの所見 がカテーテルによるものかを厳密に判別することはで きなかった。したがって，カテーテルの影響が明らか な所見についてのみ述べる.

1) ビラン

カテーテルの側壁や先端が胆管壁に接触している部 位に生じるもので, 粘膜面はフィブリンの付着のため 白く見克, 点状出血が認められた (図9). 生検標本で は粘膜上皮の剥脱, 壁内の出血や咨症性細胞浸潤がみ られた。

2) 肉芽組織の形成

カテーテルの側孔に一致して生じる肉芽組織は半球 状の隆起を示し, 黄色調で一部発赤していた（図10).

カテーテルの先端に一致して形成されるるのは円柱 状の形態をとり，色調は白色から黄色で一部に発赤が みられた。内視鏡で観察すると，胆管内にロウソクが 立っているよらな像を示しきわめて特徽的であった (図11，12，13）。病理組織学的には毛細血管の増生, 炎症性細胞浸潤, フィブリンの析出などがみられ，肉 芽組織の像を示していた（図14）.

これらの所見はカテーテル交換後 2 〜日で,すで に形成されていることもあり，比較的早期に形成され るものと考えられた。

\section{IV. 考 察}

近年, 胆道疾患に対する診断扰よび治療法の進歩に 伴って, $\mathrm{PTCD}^{1)}, \mathrm{PTCS}^{2) \sim 6)}$, 内視鏡的逆行性胆管ド
レナーシ (endoscopic retrograde biliary

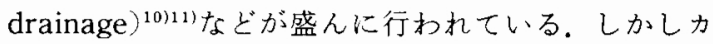
テーテルに対する胆管の組織反応を調べた研究は少な く, 塩化ビニールやシリコーンなどの材質が経験的に 用いられるに過ぎない，今回われわれは，現在，胆管 ドレナージカテーテルとしてよく用いられている塩化 ビニール, シリコンと, 今まで胆道用としては使われ ることの少なかったポリウレタンを用いて胆管壁の組 織反応の違いについて実験的に検討した。従来医療用 高分子材料に対する生体反応の検索には材料の移植局 所の組織反応を病理組織学的に検討する方法が行われ てきた ${ }^{12 / 13)}$. 最近では in vitro 試験法として組織培養 試験や溶血性試験が行われるよ5になっているが， in vivo 試験法の知見と一致しない場合もあるといわれ ている(4) -17).

胆管ドレナージカテーテルに対する組織反応を検討 するためには, in vitro 試験法で明らかにされている 材料の生体適合性を加えて, 胆汁中における組織刺激 性の変化や胆汁うっ滞, 胆管炎の影響などを考慮する 必要がある. 田中はイヌにおいて総胆管結禁のみでも 胆管壁の炎症性変化が起こり, 結合織の増生がみられ たと報告している18). われわれの実験モデルにおいて も術後早期から胆管拡張と胆道系醳素の上昇がみられ たことから胆汁らっ滞の影響が加味されていることは 除外できないが，同一サイズのカテーテルを使用した にもかかわらず，胆管壁の組穖反応に差がみられたの でそ差は主にカテーテルの材質の違いによるもの と考えられた。

胆管内留置カテーテルとして以前は主に総胆管切開 後に用いられる $\mathrm{T}$ チューブが主体であり，材質として は red rubberやラテックスゴム使われることが多 かったが，これらの材質は組織反応が強いことが知ら れていた ${ }^{16)}$. 高分子化学の進歩に伴って種々の材質が 胆道ドレナージ用カテーテルとして利用でさるよらに なり, Sanislow らはシリューン製 $\mathrm{T}$ チューブをイヌ

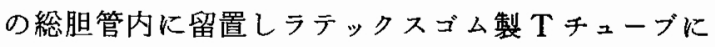
くらべ，組織反応が少ないことを報告している8．T チューブは遊離腹腔に瘦孔を形成させることが重要で あるため組織反応の強い red rubber やラテックスゴ ムが使われてきた，最近では胆管外の部分をラテック

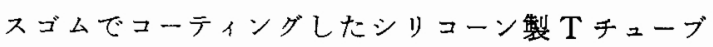
が市販されているが，これは遊離腹腔における瘦孔形 成の促進と胆管への刺激減少を目的としたものであり 有用と思われる。 
カテーテルによって起きる胆管壁の組織反応を考え る時, その原因として化学的因子と物理的因子に大別 して考完ることができる。

化学的な因子としてはカテーテルから溶出する物質 (残留モノマー，触媒，添加剤，可塑剤など)が考えら れ，物理的因子としてはカテーテルの硬度，形状が考 完られる。塩化ビニールがシリコンやポリウレタンに 比し組織反応が強いのは，今井らの in vitro 試験で明 らかにされているよらに201, 塩化ビニールに含まれる 可塑風のフタル酸ジェチルヘキシルや種々の安定剤が 溶出し組織を刺激するためと考学られているが，高分 子材料の生体反応のメカニズムは必ずしも明らかにさ れていないのが現状である。

臨床的に用いられている胆道ドレナージ用カテーテ ルの材質としては，組織反応の要因の他に，価格や加 工性，硬度なども考慮する必要がある。シリコーンは 組織反応が少ないため胆管内留置用としては優れてい るが，軟らかいためダイレーターとしては適していな い,一方，塩化ビニールは胆管壁に対する刺激は強い が，加工性，硬度の調節性なぞにすぐれているため， POCD 瘦孔の搑張には適している. 組織反応の少ない 材質は瘦孔の形成には不適であると考えられるので， 塩化ビニール製カテーテルによって瘦孔の形成および 払張をした後で、シリコーン製カテーテルを長期留置 用として使用するのがよいと考えられる。

ポリウレタンは今まで胆管ドレナージ用として用い られることは少なかったが，組織反応の程度はシリ コーンに近く，硬度を変化させることも可能であるた $ぬ^{21)}$. 今後, 胆管ドレナージ用カテーテルの材質として 利用できるものと考学られる。

次に胆管ドレナージカテーテルの刺激による胆管粘 膜の変化について内視鏡的に観察した報告は少なく，

豊田らがカテーテルによって胆管粘膜に発赤やビラン が生じることに触れているのみである6).一方, 西村ら は胆石症に和计る胆管の资症性变化について内視鏡的 観察々病理組織学的検討を行い，胆管炎の内視鏡的所 見として発赤, 浮腫, 毛細血管網, 小出血斑, 膿苔, フィブリン様物質の浮遊，ビランなどをとりあげ，こ れらの所見は組織学的には胆管の渗出性炎症像に他な らないと述べている ${ }^{22)}$. カテーテルの刺激による変化 も，われわれの実験で明らかになったように，早期に は渗出性炎症が起こり次第に結合織の増生がみられる もので，鶇沼の報告した慢性胆管炎の組織学的所見 ${ }^{23)}$ と本質的に異なるものではない.したがってその内視
鏡所見を厳密に区別寸ることは不可能であると思われ る.

今回われわれが報告したビラン，肉芽組織の形成は カテーテルが直接胆管に触れている場所に生じるるの であり，主に物理的因子の影響によるものと考学られ る.これらの所見が形成される機序として, まずカテー テルの接触により胆管粘膜の損傷が起こり, 粘膜が剥 脱して，フィブリンが析出し，それがカテーテルの側 孔や先端からカテーテルの内腔へ入り込むことにより 肉芽組織が形成されるもので，カテーテルの胆管壁へ の接触の仕方によってビランを生じたり，肉芽組織の 形成がみられたりするものと考えられる、肉芽組織が 増大してくるのはカテーテルが動脈の拍動や呼吸に 伴って移動し胆管の同じ部位に刺激を反復して加党る ためと思われる。このような所見はカテーテル挿入後 $2 \sim 3$ 日と，比較的早期に形成されるものであり，動 物実験ではこの時期には材質による組織反応の差はみ られないので，主に粘膜への物理的損傷によるものと 考えられる、したがってカテーテルの硬度や形状が胆 管壁への損傷の大きな要因になっているものと思われ る.

PTCS は他の消化器内視鏡検査と異なり, PTCD 瘦 孔という人工の経路を介して行われるため，PTCS 施 行時にはこれらの所見を念頭に置き，他の胆道粘膜病 変との鑑別に注意する必要がある。

\section{V. 結 論}

家鬼の胆管内にカテーテルを留置して胆道内瘦化も デルを作製し，シリコーン，塩化ビニール，ポリウレ タン各樹脂に対する胆管の組織反応を病理組織学的に 検討し，臨床例に打いては塩化ビニール製カテーテル に対する胆管粘膜の変化を内視鏡的, 病理組織学的に 検討し以下の結論を得た。

1）胆管内にカテーテルを留置することにより,粘膜 上皮の剥脱，炎症性細胞浸潤，結合織増生などの炎症 反応が䒩起された。

2）塩化ビニールはシリコーン，ポリウレタン，に比 し，組織反応が高度であった。

3）臨床例に拈いて,明らかにカテーテルの刺激によ る変化としてビラン，肉芽組織の形成があげられ，乙 の病理組織学的所見は, カテーテルの刺激による胆管 粘膜の剝脱とそれに続くフィブリンの析出, 肉芽組織 の形成であった。

4) 臨床例に抏いては，まず組織反応の強い塩化ビ ニール製カテーテルを用いてドレナージ瘦孔の形成拉 
よび拡大を行い，強固な瘦孔が形成された後は，胆管 壁への組織反応の少ないシリコーン製カテーテルで䇅 孔を確保し，PTCSを行らのが良いと考えられた。

稿を終えるにあたり御指導, 御校閲を賜りました塩野谷 恵彦教授に樑謝いたします。

\section{文献}

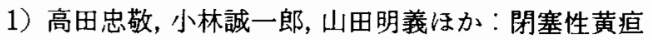
に対する経皮的肝内肝管ドレナージによる黄㡺軽 減法について一経皮的胆道鏡検查法にする孙て 一. 東京女医大誌 $42 ： 692-700,1972$

2) 二村雄次, 早川直和, 豊田澄男泀か：経皮経肝胆道 内視鏡，胃と腸 $16 ： 681-689,1981$

3) 二村雄次：胆道癌に抢ける画像診断の役割一胆道 鏡の立場から一. 腹部画像診断 $2: 73-78,1983$

4) 二次雄次, 神谷順一, 長谷川洋活加: 経皮的胆管内 視鏡。胆子膵 $4: 27-33,1983$

5）二村雄次：経皮経肝胆道鏡検查. 手技と臨床. 日臨 $42: 36-41,1984$

6）豊田澄男, 二村雄次, 弥政洋太郎：経皮経肝胆道鏡 直視下生検。最新医 $36: 327-328,1981$

7) Nudy S, Bell GD, Cowley DJ et al : Are silicon rubber $T$-tubes better than latex rubber tubes in the common bile duct? A Rhesus monkey model. Br J Surg $61: 206-208,1974$

8) Sanislow CA, Zuidema GD: The use of silicon $\mathrm{T}$-tubes in reconstructive biliary surgery in dogs. J Surg Res 3 : 497-502

9）胆道外科研究会編：外科病理. 胆道癌取扱い規約. 第 2 版, 金原出版, 東京, 1986

10) Sohendora N, Reyders FV: Palliative bile duct drainage. A new method of introducing a transpapillary drain. Endoscopy 12:8-11, 1980
11）中島正継：内視鏡的逆行性胆管ドレナージ法 (ERBD), Gastroenterol Endosc $26: 2306-2311$, 1984

12）渥美英子：合成高分子材料の生体反応，東京女医 大誌 $30: 1512-1537,1965$

13) Hosmy CA : Bio-compatibility in selection of materials for implantaion. J Biomed Mater Res $4: 341-356,1970$

14）今井庸二：医用材料の安全性.化学総説 $21 ： 55$ $-84,1978$

15）増原英一，今井庸二：医用高分子材料の問題点. 医 科器械学 $42: 685-689,1972$

16）前川昭彦：バイオマテリフルの生体反応。病態生 理 $3: 372-378,1984$

17）佐藤温重：異物资症反応の細胞生理。病態生理 $3: 359-365,1984$

18）田中正一：ジスキネジー犬(福島)に於ける総胆管 及び肝内胆管の病理組織学的研究. 弘前医 11 : $282-292,1960$

19) Winstone NE, Golby MGS, Lawson LJ et al : Biliary peritonitis : A hazard of polyvinyl chloride T-tubes. Lancet $1: 843-844,1965$

20）今井庸二, 渡辺昭彦, 増原英一：医用材料としての 軟質ポリ塩化ビニールの評価.人工䁍器 4: 270 $-274,1975$

21）松浦義勝, 西本 洋, 岡谷 進ほか: 熱可塑性ポリ ウレタン樹脂の動的粘弾性と機械的特性. 武田研 究所報 $42: 313-323,1983$

22）西村 明, 日浦利明, 大津裕司：胆石疾患に打ける 胆道炎の内視鏡的分類とその病理組織学的検討. Gastroenterol Endosc $20: 514-524 ， 1978$

23）鵜沼俊郎：各種胆道疾患に於ける総胆管の病理組 織学的研究. 弘前医 $10: 471-480,1959$ 